\title{
Japan plans to label 'detectable' GM food
}

[TOKYO] Japan's Ministry of Agriculture, Forestry and Fisheries last week unveiled draft regulations stipulating the mandatory labelling of 28 food products containing detectable genetically modified (GM) ingredients, including soya beans, maize and potatoes.

The rules were approved by the ministry's committee on GM food labelling on Tuesday (10 August). Any foods with 5 per cent or more DNA or protein from GM crops would have to be labelled.

The regulations also specify that products resulting from the mixture of GM and nonGM foodstuffs should be labelled as 'undifferentiated'. Products that lose protein and genetic material from GM crops in the production process, such as soy sauce, would not need labelling (see Nature 395, 628; 1998).

The ministry's plan, which will come into effect next April, has provoked strong criticism from industry and consumer groups. Japanese companies are concerned that the regulations will lead to trade friction with exporters of GM foods, in particular the United States. They also fear that the prices of their products will be driven up because of the high cost of carrying out tests to identify foods containing GM elements.

Many food manufacturers plan to switch to suppliers that provide GM-free crops, but this will not be easy. Japan imports almost 60 per cent of its agricultural products, mainly from the United States, where identification of GM ingredients is not required. Switching to domestically produced GM-free ingredients could double the cost of products, according to industry analysts.

"You have to raise the price of the products, and one wonders whether this is what consumers want in exchange for having a few GM foods labelled," says Yoshinori Komura, a member of the ministry's committee on GM organisms and director of the Japan Vegetable Oil Association. He points out that there are no approved tests for detecting GM molecules in Japan.

Consumer groups, on the other hand, say the draft regulations should be more stringent if the main aim is to respect the right of the consumer to know whether a product contains GM components.

"We are not interested whether the product contains a detectable amount of GM products or not. We want to know whether it contains such products at all," says Satoko Tanaka, a representative of civil rights groups in Tokyo.

"Labelling products with undifferentiated ingredients would only confuse the public," says Yasue Ito, director of the Consumer Science Federation. "This is just avoiding the need to track down the genetic history of the ingredients."

Ito points out that differentiation of GM and non-GM products should be made possible by the exporters isolating crops more effectively.

Japanese companies involved in the development of GM crops have become increasingly pessimistic about commercializing their products. Japan Tobacco and Suntory are carrying out farm-scale trials of GM crops, including virus-resistant rice. They say they have no immediate plans to release any of their products on the market.

Some companies have commercialized GM flowers, including blue carnations. But none is exploiting the food market, out of concern that this could give the company a negative image.

AsakoSaegusa

\section{Tension stays high as US optical societies launch merger ballot}

[SAN DIEGO] The proposed merger of the two leading US optical-science societies has turned into a bruising political campaign as voting began last week among the more than 26,500 combined members.

As the Optical Society of America (OSA) and the International Society of Optical Engineers (SPIE) started sending out ballot papers, charges of unfair and unethical tactics were already flying.

The infighting is concentrated within OSA, whose 12,500 members are largely academic scientists. Proponents of the merger, who include the leaders of both organizations, argue that it will strengthen the role of optics science.

But critics fear that scientists will get short shrift if merged with SPIE's 14,000 members, who are primarily engineers. Some OSA scientists see the merger "as an attack on their livelihood" as it could diminish their role in the society, for which they earn credit that advances their academic careers.

They are accusing the organization's leaders of trying to improperly influence the election. As an example of inappropriate leadership tactics, they cite the fact that OSA's executive director recently contacted SPIE members offering OSA membership at half price along with the opportunity "to cast an historic vote" in the OSA election.

Among some rank and file OSA members

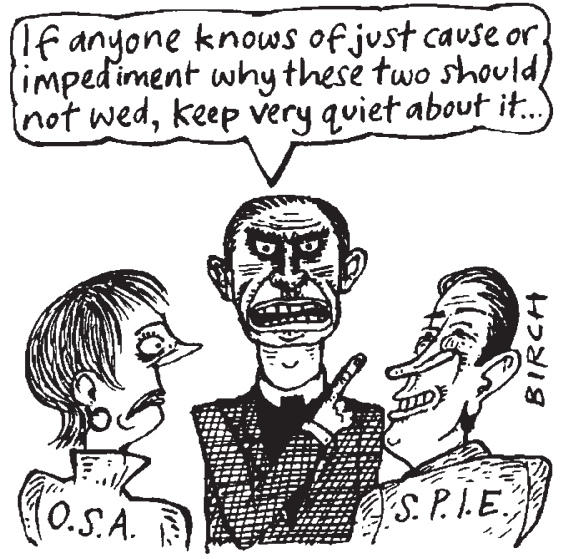

there is deep resentment towards the leadership's stance. "It has become really reprehensible," says Kenneth Alexander, a visual psychophysicist at the University of Illinois at Chicago's College of Medicine.

As chairman of the OSA's division of vision and colour, Alexander recently tried to e-mail a brief notification of the merger vote to the approximately 400 scientists in his division. But the e-mail was blocked by Anthony E. Siegman, president of OSA and an emeritus professor of electrical engineering at Stanford University.

Another OSA scientist was threatened with legal action by the society's executive director for using a society mailing list to send out a notice on the merger.
Siegman rejects allegations that he and other advocates of the merger are trying to influence the election result. "The initiative for unification is the product of a very long, careful and arduous effort by distinguished OSA members" to present all sides of the issue, he says, pointing out that repeated OSA board votes have overwhelmingly approved the merger proposal.

OSA's membership solicitation to SPIE members was a routine recruitment effort, Siegman says, denying that it was aimed at manipulating voting. He adds that limiting the use of the society's mailing list is in line with a long-standing policy to protect society members from unnecessary correspondence.

Paul Foreman, chairman of OSA's merger task force and a leading advocate of the merger, accuses some of the critics of paranoia, claiming that they have disseminated false information about the merger and are impossible to satisfy. What they are doing is "a disservice to the profession", he says.

There appears to be little ferment within SPIE, although its treasurer, Charles DeMund, voted against the merger "because it is like two people, who are not getting along while dating, getting married".

The OSA election will be held on 29 September during its annual meeting in Santa Clara, California. Rex Dalton 